\title{
Analisis Keuangan Pemerintah Provinsi Sumatera Selatan dan Pemerintah Provinsi Kepulauan Bangka Belitung
}

\author{
Fery Panjaitan \\ STIE-IBEK Bangka, fery panjaitan@yahoo.co.id
}

\begin{abstract}
Good regional financial management will affect the progress of an area. Thus an area whose financial performance is said to be good, could mean the region has the financial capacity to finance the implementation of regional autonomy following accordance with Indonesian Law Number 32 of 2004 concerning Regional Government and Indonesian Law Number 33 of 1999 concerning Financial Balance Between the Central Government and regions. This study aims to analyze the financial condition of the Bangka Belitung Islands Province and South Sumatra Province in the 2014-2018 fiscal year using the Mann-Whitney $U$ Test. The results showed that the Province of Bangka Belitung Islands had better financial conditions than the Province of South Sumatra over the tax ratio, the ratio of capital expenditure to total regional expenditure, and the ratio of capital expenditure to the population while the Province of South Sumatra had a better level of the financial condition than the Province Bangka Belitung Islands for the ratio of indirect employee expenditure to total regional expenditure. The conclusion of this study is the Province of Bangka Belitung Islands can reduce indirect employee expenditure, the reduction is needed to increase capital expenditure because large capital expenditure has a significant influence on the economic growth of an area other than the private sector, households, and abroad.
\end{abstract}

Keywords: Regional financial condition, ratio analysis

\begin{abstract}
ABSTRAK
Pengelolaan keuangan daerah yang baik akan mempengaruhi kemajuan suatu daerah. Dengan demikian daerah yang kinerja keuangannya dikatakan baik, dapat diartikan daerah tersebut memiliki kemampuan keuangan untuk membiayai penyelenggaraan otonomi daerah sesuai dengan UndangUndang Nomor 32 Tahun 2004 tentang Pemerintahan Daerah dan Undang-Undang Republik Indonesia Nomor 33 Tahun 1999 tentang Perimbangan Keuangan Antar Daerah. Pemerintah Pusat dan Daerah. Penelitian ini bertujuan untuk menganalisis kondisi keuangan Provinsi Kepulauan Bangka Belitung dan Provinsi Sumatera Selatan pada tahun anggaran 2014-2018 menggunakan Mann-Whitney U Test. Hasil penelitian menunjukkan bahwa Provinsi Kepulauan Bangka Belitung memiliki kondisi keuangan yang lebih baik dibandingkan Provinsi Sumatera Selatan atas tax ratio, rasio belanja modal terhadap total belanja daerah, dan rasio belanja modal terhadap penduduk sedangkan Provinsi Sumatera Selatan. memiliki tingkat kondisi keuangan yang lebih baik dibandingkan Provinsi Kepulauan Bangka Belitung untuk rasio belanja pegawai tidak langsung terhadap total belanja daerah. Kesimpulan dari penelitian ini adalah Provinsi Kepulauan Bangka Belitung dapat menurunkan belanja pegawai tidak langsung, pengurangan tersebut diperlukan untuk meningkatkan belanja modal karena belanja modal yang besar mempunyai pengaruh yang signifikan terhadap pertumbuhan ekonomi suatu daerah selain sektor swasta, rumah tangga, dan di luar negeri.
\end{abstract}

Kata kunci : Kondisi keuangan daerah, analisis rasio

\section{A. PENDAHULUAN}

Diberlakukannya Undang-Undang RI Nomor 32 Tahun 2004 Tentang Pemerintahan Daerah dan Undang-Undang RI Nomor 33 Tahun 1999 Tentang Perimbangan Keuangan Antara Pemerintah Pusat dan Daerah, memiliki arti penting 
dan membawa perubahan yang mendasar dalam kehidupan sistem ketatanegaraan di Indonesia, khususnya sistem pemerintahan Pusat dan Daerah serta sistem hubungan keuangan antara Pemerintah Pusat dengan Pemerintah Daerah.

Dengan demikian kedua undang-undang tersebut memberikan peluang yang seluas-luasnya bagi daerah, termasuk Daerah Kabupaten/Kota untuk melaksanakan otonomi daerah, yakni mengatur dan mengurus kepentingan masyarakat dan daerahnya sesuai kewenangan yang dimilikinya dengan mengoptimalkan berbagai potensi dan sumber daya guna peningkatan kemandirian daerah dan mewujudkan kesejahteraan masyarakat dalam wilayah daerahnya masing-masing. Melalui regulasi sesuai paradigma dalam kedua undang-undang tersebut, juga menyiratkan keinginan perubahan dalam mekanisme hubungan Pusat dan Daerah, yang sebelumnya terkesan sangat desentralistik.

Pemihakan terhadap desentralisasi merupakan keniscayaan dalam perjalanan negara-bangsa Indonesia yang sedang berproses menuju demokratisasi. Desentralisasi akan memberikan keleluasaan pada daerah untuk mengurus, mengatur, mengelola kewenangan, dan keuangan secara mandiri.

Berdasarkan kinerja PAD dengan metode Indeks Kemampuan Keuangan (IKK) yang dilakukan oleh deddyk@bappenas.go.id , diketahui bahwa bahwa Sumatera Selatan merupakan Provinsi dengan kinerja yang tinggi sedangkan Bangka Belitung merupakan Provinsi yang memiliki kinerja rendah walaupun demikian Provinsi Bangka Belitung mempunyai Pertumbuhan PAD yang cukup besar (1956,39\%) dibandingkan dengan Provinsi lainnya.

Pengelolaan keuangan daerah yang baik akan berpengaruh terhadap kemajuan suatu daerah. Pengelolaan keuangan daerah yang dilakukan secara ekonomis, efisien, dan efektif atau memenuhi prinsip value for money serta partisipasi, transparansi, akuntabilitas, dan keadilan akan dapat mendorong pertumbuhan ekonomi (Rasdalima, 2017). Pengelolaan keuangan daerah yang baik tidak hanya membutuhkan sumber daya manusia yang handal, tetapi juga harus didukung oleh kemampuan keuangan daerah yang memadai. Pengukuran kinerja keuangan pada pemerintah daerah juga digunakan untuk menilai akuntabilitas dan kemampuan keuangan daerah dalam penyelenggaraan otonomi daerah. Dengan demikian maka suatu daerah yang keuangannya dinyatakan baik berarti daerah tersebut memiliki kemampuan keuangan untuk membiayai pelaksanaan otonomi daerah. Menurut Bank Indonesia melalui Kajian Ekonomi Keuangan Regional perkembangan realisasi anggaran Provinsi Sumatera Selatan dan Provinsi Bangka Belitung tahun 2014-2018 terlihat seperti tabel dibawah ini :

Tabel Realisasi Anggaran

Provinsi Sumatera Selatan dan Provinsi Kepulauan Bangka Belitung Tahun (2014-2018)

\begin{tabular}{|c|c|c|c|c|c|c|}
\hline \multirow{2}{*}{ Tahun } & \multicolumn{3}{|c|}{ Pendapatan } & \multicolumn{3}{c|}{ Belanja } \\
\cline { 2 - 7 } & $\begin{array}{c}\text { Anggaran } \\
\text { (Rp.Miliar) }\end{array}$ & $\begin{array}{c}\text { Realisasi } \\
\text { (Rp.Miliar) }\end{array}$ & $\begin{array}{c}\text { \% } \\
\text { Realisasi }\end{array}$ & Anggaran & $\begin{array}{c}\text { Realisasi } \\
\text { (Rp.Miliar) }\end{array}$ & $\begin{array}{c}\% \\
\text { Realisasi }\end{array}$ \\
\hline 2014 & $6,483.0$ & $6,252.1$ & 96.4 & $6,048.6$ & $5,781.5$ & 95.6 \\
\hline 2015 & $6,883.9$ & $5,869.5$ & 85.26 & $6,452.6$ & $5,169.0$ & 80.1 \\
\hline 2016 & $7,036.8$ & $6,582.8$ & 93.55 & $5,425.9$ & $4,911.9$ & 90.53 \\
\hline 2017 & $8,911.5$ & $8,196.0$ & 91.97 & $6,439.5$ & $5,793.4$ & 89.97 \\
\hline 2018 & 9,196 & 9,141 & 99.40 & 7,427 & 6,764 & 91.07 \\
\hline
\end{tabular}




\begin{tabular}{|c|c|c|c|c|c|c|}
\hline \multirow{2}{*}{ Tahun } & \multicolumn{3}{|c|}{ Pendapatan } & \multicolumn{3}{c|}{ Belanja } \\
\cline { 2 - 7 } & $\begin{array}{c}\text { Anggaran } \\
\text { (Rp.Miliar) }\end{array}$ & $\begin{array}{c}\text { Realisasi } \\
\text { (Rp.Miliar) }\end{array}$ & $\begin{array}{c}\% \\
\text { Realisasi }\end{array}$ & Anggaran & $\begin{array}{c}\text { Realisasi } \\
\text { (Rp.Miliar) }\end{array}$ & $\begin{array}{c}\% \\
\text { Realisasi }\end{array}$ \\
\hline 2014 & $1,722.42$ & $1,720.59$ & 99.89 & 1,924 & $1,194.56$ & 83.79 \\
\hline 2015 & $1,918.08$ & $1,906.11$ & 99.38 & $2,226.35$ & $1,890.21$ & 84.90 \\
\hline 2016 & $2,017.17$ & $1,946.46$ & 96.64 & $2,354.86$ & $2,084.04$ & 88.50 \\
\hline 2017 & $2,386.29$ & $2,248.41$ & 90.96 & $2,598.99$ & $2,363.97$ & 90.96 \\
\hline 2018 & $2,487.06$ & $2,557.13$ & 102.82 & $2.596,70$ & $2,360.96$ & 90,92 \\
\hline
\end{tabular}

Sumber : BI, KEKR Sumatera Selatan dan Bangka Belitung 2014-2018.

Realisasi pendapatan dan belanja Pemerintah Daerah Sumatera Selatan tahun 2015 melambat dibandingkan dengan tahun 2014 . Realisasi pendapatan tercatat sebesar Rp. $5,869,5$ trilun atau 85,26\%, lebih rendah dibandingkan serapan pendapatan tahun 2014 yang sebesar 96,4\%. Sementara itu, realisasi belanja tahun 2015 sebesar Rp.5,169,0 triliun atau 80,1\% terhadap APBD 2015, lebih rendah dibandingkan realisasi belanja tahun 2014 sebesar 95,6\%. Hingga akhir tahun 2015 realisasi pendapatan daerah lebih tinggi daripada belanja daerah sehingga terjadi surplus sebesar Rp.700,5 miliar atau sebesar $13,6 \%$ dari total belanja.

Pendapatan di triwulan IV 2016 tercatat sebesar Rp.6,529,3 triliunatau 93\% terhadap APBD 2016, lebih tinggi dibandingkan realisasi pendapatantriwulan IV 2015 yang sebesar 85,26\%. Sementara itu, realisasi belanja triwulan IV2016 sebesar Rp.4,04 triliun atau 89,93\% terhadap APBD 2016, lebih tinggidibandingkan realisasi belanja triwulan III 2015 yang sebesar $80,1 \%$.

Untuk tahun 2017, realisasi pendapatan mencapai $91,97 \%$ dari total pagu yang dianggarkan, lebih rendah dibandingkan capaian periode yang sama tahun 2016 sebesar 93,55\% dari pagu. Sedangkan, realisasi belanja mencapai $89,97 \%$ dari total pagu, lebih kecil sedikit dibandingkan periode yang sama tahun sebelumnya sebesar $90,53 \%$.

Realisasi anggaran pendapatan tahun 2018 mencapai Rp. 9,141 triliun dari pagu anggaran sebesar Rp. 9,196 triliun. Angka ini lebih tinggi dibandingkan capaian tahun 2017 yang tercatat sebesar $99,40 \%$ dari pagu. Sedangkan realisasi belanja untuk trieulan ke IV tahun 2018 mencapai 91,07\% dari total anggaran sebesar Rp/ 7,427 triliun atau sebesar Rp 6,764 triliun. Pencapaian ini lebih baik dibandingkan realisasi periode yang sama tahun sebelumnya yaitu sebesar 89,97\% atau sebesar Rp. 5,793,4 triliun.

Realisasi pendapatan dan belanja Pemerintah Daerah Bangka Belitung tahun 2015 sebesar $\operatorname{Rp} 1,90$ triliun atau 99,38\% dari keseluruhan target pendapatan tahun 2015 sebesar Rp 1,91 triliun, Sementara realisasi belanja pada tahun 2015 sebesar Rp 1,89 triliun atau tercapai $89,90 \%$ dari rotal rencana belanja daerah.

Realisasi pendapatan daerah pada tahun 2016 mencapaiRp1,94 triliun atau 96,64\% dari total pendapatan yangdirencanakan sebesar Rp2,01 triliun, menurun dibandingkantahun sebelumnya yang mencapai 99,38\%. Dana perimbanganmasih menjadi penyumbang terbesar pada pendapatan daerahProvinsi Kepulauan Bangka Belitung dengan pangsa sebesar61,04\% dari total pendapatan daerah. Realisasi danaperimbangan pada tahun 2016 sebesar Rp1,19 triliun atautercapai sebesar 83,18\% dari target tahun 2016, menurun dibandingkan tahun sebelumnyayang tercapai sebesar 95,84\%. Realisasi terbesar dari dana perimbangan adalah pos dana alokasiumum sebesar Rp905,52 miliar atau 76,08\% dari total dana perimbangan.

Realisasi belanja daerah pada tahun 2016 mencapaiRp2,08 triliun atau sebesar $88,50 \%$ dari total belanja yangdirencanakan sebesar $\mathrm{Rp} 2,35$ triliun, meningkat dibandingkantahun sebelumnya yang tercapai sebesar $84,90 \%$. Dari totalrealisasi belanja tersebut, sebesar Rp1,21 triliun merupakanbelanja tidak langsung atau dengan pangsa sebesar 58,06\% daritotal belanja tahun 2016. Sedangkan sisanya merupakan 
belanjalangsung sebesar Rp874,01 miliar atau dengan pangsa sebesar41,93\% dari total belanja.

Realisasi pendapatan daerah Provinsi Kepulauan Bangka Belitung pada tahun 2017 mencapai Rp2,48 triliun atau 90,96\% dari total pendapatan yang direncanakan sebesar Rp2,38 triliun, menurun dibandingkan realisasi tahun sebelumnya yang mencapai 96,64\%. Sedangkan realisasi belanja daerah Provinsi Kepulauan Bangka Belitung pada tahun 2017 mencapai Rp2.363,97 miliar atau sebesar 90,96\% dari total belanja yang direncanakan sebesar Rp2,598 triliun, meningkat dibandingkan realisasi tahun sebelumnya yang tercapai sebesar $88,50 \%$.

Realisasi pendapatan daerah tahun 2018 mencapai Rp. 2,55 triliun, lebih tinggi dibandingkan tahun 2017 sebesar Rp. 2,24 triliun. Dari perbandingan capaian realisasi terhadap target, persentase realisasi pendapatan daerah tahun 2018 sebesar 102,82\% juga tercatat lebih tinggi dibandingkan tahun 2017 yang mencapai 94,22\%.

Penelitian ini bertujuan untuk menganalisiskondisi keuangan Pemerintah Provinsi Kepulauan Bangka Belitung dan Pemerintah Provinsi Sumatera Selatan selama tahun anggaran 2014-2018, dan menguji apakah kondisikeuangan Pemerintah Provinsi Kepulauan Bangka Belitung berbeda dengan kondisi keuangan Pemerintah Provinsi Sumatera Selatan selama tahun anggaran 2014-2018, ditinjau dari rasio pajak (tax ratio), rasio ruang fiskal daerah, rasio kemandirian daerah, rasio belanja pegawai terhadap total belanja daerah, rasio belanja pegawai tidak langsung terhadap total belanja daerah, rasio belanja modal terhadap total belanja daerah, rasio belanja daerah terhadap jumlah penduduk, dan rasio belanja modal terhadap jumlah penduduk.

\section{B. LANDASAN TEORI}

\section{1) PENGERTIAN KEUANGAN DAERAH}

Menurut UU Nomor UU Nomor 23 tahun 2014. Keuangan Daerah adalah semua hak dan kewajiban daerah yang dapat dinilai dengan uang dan segala sesuatu berupa uang dan barang yang dapat dijadikan milik daerah yang berhubungan dengan pelaksanaan hak dan kewajiban tersebut.

Menurut PP Nomor 58 tahun 2005 keuangan daerah adalah semua hak dan kewajiban daerah dalam rangka penyelenggaraan pemerintahan daerah yang dapat dinilai dengan uang termasuk didalamnya segala bentuk kekayaan yang berhubungan dengan hak dan kewajiban daerah tersebut

\section{2) PRINSIP MANAJEMEN KEUANGAN DAERAH}

\section{a) Akuntabilitas}

Pengambilan suatu keputusan sesuai dengan mandat yang diterima. Kebijakan harus dapat diakses dan dikomunikasikan

b) Value for Money

Prinsip ini dioperasionalkan dalam pengelolaan keuangan daerah dan anggaran daerah dengan ekonomis, efektif, dan efisien

c) Kejujuran dalam mengelola keuangan publik

Dalam pengelolaan harus dipercayakan kepada pegawai yang punya integritas dan kejujuran yang tinggi.

d) Transparansi

Keterbukaan pemerintah dalam membuat kebijakan keuangan daerah sehingga dapat diawasi oleh DPRD dan Masyarakat.

e) Pengendalian

Monitoring terhadap penerimaan maupun pengeluaran APBD 


\section{3) PENGELOLAAN KEUANGAN DAERAH}

Pengelolaan dilaksanakan oleh pemegang kekuasaan pengelola keuangan daerah. Kepala daerah selaku kepala pemerintah daerah adalah pemegang kekuasaan pengelolaan keuangan daerah dan mewakili pemerintah daerah dalam kepemilikan kekayaan daerah yang dipisahkan.

\section{4) APBD}

Anggaran Pendapatan, dan Belanja Daerah (APBD), adalah rencana keuangan tahunan pemerintah daerah di Indonesia yang disetujui oleh Dewan Perwakilan Rakyat Daerah. APBD ditetapkan dengan APBD terdiri atas:

a) Anggaran pendapatan

> Pendapatan Asli Daerah (PAD), yang meliputi : pajak daerah, retribusi daerah, hasil pengelolaan kekayaan daerah, dan penerimaan lain-lain.

$>$ Bagian dana perimbangan, yang meliputi dana bagi hasil, aana alokasi umum (DAU) dan dana alokasi khusus (DAK).

$>$ Lain-lain pendapatan yang sah seperti dana hibah atau dana darurat.

b) Anggaran belanja, yang digunakan untuk keperluan penyelenggaraan tugas pemerintahan di daerah.

c) Pembiayaan, yaitu setiap penerimaan yang perlu dibayar kembali dan/atau pengeluaran yang akan diterima kembali, baik pada tahun anggaran yang bersangkutan maupun tahun-tahun anggaran berikutnya. Peraturan Daerah. Tahun anggaran APBD meliputi masa satu tahun, mulai dari tanggal 1 Januari sampai dengan tanggal 31 Desember.

\section{5) RASIO KEUANGAN DAERAH}

a) Rasio Pajak (Tax Ratio)

Perbandingan pajak terhadap pendapatan suatu perekonomian (economy), selanjutnyadalam analisis ini disebut rasio pajak (tax ratio), merupakan perbandingan antara jumlahpenerimaan pajak dengan pendapatan suatu perekonomian. Dalam konteks keuangan negara,rasio pajak merupakan perbandingan antara pajak suatu negara dengan Pendapatan DomestikBruto (PDB), sedangkan di tingkat daerah rasio pajak merupakan rasio antara pajak daerahwilayah perekonomian daerah tersebut dengan Pendapatan Domestik Regional Bruto (PDRB).

Angka rasio pajak suatu daerah dipengaruhi oleh PDRB.PDRB dapat dilihat dari tiga sisi: produksi, pengeluaran, serta pendapatan. Di sisiproduksi, PDRB mengindikasikan kegiatan ekonomi suatu daerah yang secara umum dapatdigambarkan melalui kemampuan daerah tersebut menghasilkan barang dan jasa yangdiperlukan bagi kebutuhan hidup masyarakat pada periode tertentu.

Dari sisi pengeluaran,PDRB menggambarkan keseluruhan pengeluaran yang dilakukan oleh sektor-sektor ekonomiyang ada di suatu wilayah pada periode tertentu yaitu sektor rumah tangga (berupa konsumsirumah tangga), sektor swasta (pembentukan barang modal/investasi), sektor pemerintah(konsumsi pemerintah di luar pembayaran non jasa /transfer non payment), serta sektor luarnegeri (ekspor dan impor). Sementara itu, di sisi pendapatan, PDRB menggambarkan jumlahpendapatan yang diterima penduduk wilayah tersebut pada suatu periode berupa gaji dansejenisnya, sewa modal, bunga dan sejenisnya, serta laba yang dihasilkan oleh pengusaha.Dari sisi mana pun PDRB diukur akan dihasilkan angka yang sama (setelah dilakukanpenyesuaian dan koreksi).

Terkait dengan rasio pajak, PDRB menggambarkan jumlah pendapatan potensial yangdapat dikenai pajak. PDRB juga menggambarkan kegiatan ekonomi masyarakat yang jikaberkembang dengan baik merupakan potensi yang baik bagi pengenaan pajak di 
wilayahtersebut. Oleh karena itu, mengetahui angka-angka rasio pajak di berbagai wilayah di Indonesiaakan membantu kita dalam menganalisis secara sederhana hubungan antara pajak daerahwilayah tersebut dengan PDRB-nya, mengetahui jenis-jenis pajak apa saja yang potensial sertasektor ekonomi yang terkait, dan menilai kondisi suatu daerah dengan membandingkannyadengan daerah lain

\section{b) Rasio Ruang Fiskal (Fiscal Space)}

Mengacu kepada laporan Fiscal Policy for Growth and Development (World Bank, 2006) dinyatakan bahwa ruang fiskal (fiscal space) tersedia, jika pemerintah dapat meningkatkan pengeluarannya tanpa mengancam solvabilitas fiskal (fiscal solvency). Stephen S. Heller (IMF Policy Discussion Paper, 2005) mengemukakan bahwa ruang fiskal dapat didefinisikan sebagai ketersediaan ruang yang cukup pada anggaran pemerintah untuk menyediakan sumber daya tertentu dalam rangka mencapai suatu tujuan tanpa mengancam kesinambungan posisi keuangan pemerintah. Ruang fiskal diperoleh dari pendapatan umum setelah dikurang pendapatan yang sudah ditentukan penggunaannya (earmarked) serta belanja yang sifatnya mengikat seperti belanja pegawai dan belanja bunga.

Ruang fiskal bisa juga muncul dari peningkatan pendapatan di berbagai sektor dan penurunan kewajiban pembayaran utang. Selain itu, efektivitas penggunaan anggaran di suatu daerah juga menunjang terciptanya ruang fiskal yang cukup memberi ruang dalam pembangunan suatu daerah. Dalam hal ini, perencanaan dan penganggaran yang dituangkan dalam APBD suatu daerah memegang peranan sangat penting. Pemerintah daerah diharapkan memiliki terobosan untuk memanfaatkan ruang fiskal yang ada guna memacu pertumbuhan ekonomi.

Stimulus berupa kebijakan yang mampu menciptakan iklim perekonomian yang kondusif sangatlah diharapkan. Sektor riil seperti perdagangan dan perkembangan usaha kecil dan menengah yang selama ini masih belum optimal, harus diberi dukungan kebijakan dari pemerintah. Terkait dengan iklim investasi di suatu daerah, setidaknya ada dua hal yang perlu diperhatikan. Yang pertama adalah kelompok kebijakan pemerintah yang memengaruhi biaya seperti pajak, beban regulasi dan pungli, korupsi, infrastruktur, biaya operasi, dan investasi perusahaan, dan yang kedua, kelompok yang mempengaruhi risiko yang terdiri dari stabilitas makroekonomi, prediktibilitas kebijakan, hak properti, kepastian kontrak, dan hak untuk mentransfer keuntungan.

\section{c) Rasio Kemandirian Daerah}

Rasio kemandirian ditunjukkan oleh rasio PAD terhadap total pendapatan serta rasio transfer ke daerah (termasuk di dalamnya dana perimbangan) terhadap total pendapatan. Dua rasio yang mewakili tersebut, meskipun menunjukkan kemandirian daerah, namun memiliki makna yang berbeda atas angka-angkanya. Rasio PAD terhadap totalnya memiliki makna yang berkebalikan dengan rasio transfer terhadap total pendapatan.

Semakin besar angka rasio PAD maka kemandirian daerah semakin besar. Sebaliknya, makin besar angka rasio transfer, maka akan semakin kecil tingkat kemandirian daerah dalam mendanai belanja daerah. Oleh karena itu, daerah yang memiliki tingkat kemandirian yang baik adalah daerah yang memiliki rasio PAD yang tinggi sekaligus rasio transfer yang rendah.

d) Rasio Belanja Pegawai Terhadap Total Belanja Daerah

Rasio ini memperlihatkan rasio belanja pegawai terhadap belanja daerah. Semakin tinggi angka rasionya maka semakin besar proporsi APBD yang dialokasikan untuk belanja pegawai dan begitu sebaliknya semakin kecil angka rasio belanja pegawai maka 
semakin kecil pula proporsi APBD yang dialokasikan untuk belanja pegawai APBD. Belanja pegawai yang dihitung dalam rasio ini melipui belanja pegawai langsung dan belanja pegawai tidak langsung.

e) Rasio Belanja Pegawai Tidak Langsung Terhadap Total Belanja Daerah

Rasio belanja pegawai tidak langsung terhadap total belanja daerah mencerminkan porsi belanja daerah terhadap pembayaran gaji pegawai PNSD. Semakin besar rasionya maka semakin besar belanja daerah yang dibelanjakan untuk membayar gaji pegawai daerah dan sebaliknya, semakin kecil angka rasionya maka semakin kecil belanja daerah yang dipergunakan untuk membayar gaji pegawai daerah.

\section{f) Rasio Belanja Modal Terhadap Total Belanja Daerah}

Rasio belanja modal terhadap total belanja daerah untuk belanja modal. Belanja mencerminkan porsi belanja daerah yang dibelanjakan modal sendiri ditambah belanja barang dan jasa, merupakan belanja pemerintah yang memiliki pengaruh signifikan terhadap pertumbuhan ekonomi suatu daerah selain dari sektor swasta, rumah tangga, dan luar negeri. Oleh karena itu, semakin tinggi angka rasionya, semakin baik pengaruhnya terhadap pertumbuhan ekonomi. Sebaliknya, semakin rendah angkanya, semakin buruk pengaruhnya terhadap pertumbuhan ekonomi.

\section{g) Rasio Belanja Daerah Terhadap Jumlah Penduduk}

Rasio belanja daerah terhadap jumlah penduduk (belanja daerah perkapita) menunjukkan seberapa besar belanja yang digunakan untuk menyejahterakan per penduduk di suatu daerah. Semakin besar nilainya, semakin besar besar belanja yang dikeluarkan untuk menyejahterakan satu orang penduduk wilayah tersebut sehingga semakin besar kemungkinan tercapainya. Sebaliknya, semakin kecil angka rasionya, semakin kecil dana yang disediakan pemda untuk menyejahterakan penduduknya. Namun demikian, rasio ini sebaiknya juga dirinci lagi menjadi per jenis belanja perkapita sehingga akan lebih memperlihatkan kontribusi dari setiap jenis belanja sebagai faktor pendorong pertumbuhan ekonomi.

h) Rasio Belanja Modal Terhadap Jumlah Penduduk

Rasio belanja modal perkapita menunjukkan seberapa besar belanja yang dialokasikan pemerintah untuk pembangunan infrastruktur daerah per penduduk. Rasio belanja modal perkapita memiliki hubungan yang erat dengan pertumbuhan ekonomi karena belanja modal merupakan salah satu jenis belanja pemerintah yang menjadi pendorong pertumbuhan ekonomi. Rasio ini bermanfaat untuk menunjukkan perhatian pemerintah dalam meningkatkan perekonomian penduduknya dari pembangunan infrastruktur yang dikeluarkan

\section{METODOLOGI PENELITIAN}

Penelitian ini merupakan penelitian kuantitatif dengan analisis data sekunder (ADS) atau disebut juga dengan secondary data analysis atau existing statisticyang memiliki karakter yang hampir sama dengan analisis isi. Perbedaannya adalah, bila dalam analisis isi, peneliti memanfaatkan data berupa simbol-simbol dari media atau teks tertentu dan peneliti sendirilah yang mengolah data sedemikian rupa sehingga data tersebut dapat memiliki arti, sedangkan dalam ADS, peneliti cukup memanfaatkan data yang sudah matang yang diperoleh dari Bank Indonesia melalui buku Kajian Ekonomi dan Keuangan RegionalBangka Belitung dan Sumatera Selatanyang kemudian diolah dan dianalisis untuk mendapatkan informasi ilmiah (Suharyadi \& Purwanta, 2008). 
Unit analisis dalam penelitian ini adalah Pemerintah Bangka Belitung dan Sumatera Selatan. dalam jangka waktu 5 (lima) tahun anggaran, yaitu dari tahun 2014 sampai dengan tahun 2018. Penarikan sampel dilakukan dengan metode purposive sampling, dengan cara judgment sampling, yaitu teknik pengambilan sampel untuk memenuhi suatu kriteria tertentu. (Arikunto, 2006)

Pengujian statistik mempergunakan Uji Mann-Whitney $U$ yaitu uji beda untuk dua sampel independen/ bebas yang berukuran tidak sama dan tidak terpenuhinya asumsi distribusi normal terhadap data berskala interval atau rasio. Terdapat dua teknik yang berbeda dalam pengujian Mann-Whitney, yaitu ketika jumlah sampel kecil $\left(n_{1}\right.$ ataun $\left.n_{2} \leq 20\right)$, dan ketika jumlah sampel besar $\left(n_{1}\right.$ ataun $\left.2>20\right)$, dalam penelitian ini jumlah sampel adalah kecil.Uji ini digunakan untuk mengetahui ada atau tidaknya perbedaan rata-rata antara dua kelompok sampel yang tidak berhubungan satu sama lain, yaitu APBD Provinsi Bangka Belitung dan APBD Provinsi Sumatera Selatan. Jika ada perbedaan, maka akan terlihat rata-rata manakah yang lebih tinggi. Adapun tahapan pengujian meliputi :

1. Menyusun kedua hasil pengamatan menjadi satu kelompok sampel.

2. Menghitung jenjang/rangking untuk tiap-tiap nilai dalam sampel gabungan.

3. Jenjang atau rangking diberikan mulai dari nilai terkecil sampai terbesar.

4. Nilai beda sama diberi jenjang rata-rata

5. Menjumlahkan nilai jenjang untuk untuk masing-masing sampel.

6. Menghitung nilai $U$ dengan menggunakan rumus sebagai berikut :

$$
\begin{aligned}
& n_{2}\left(n_{2}+1\right) \\
& U_{1}=\frac{n_{1} n_{2}+-\sum R_{1}}{2} \\
& n_{1}\left(n_{1}+1\right) \\
& U_{2}=n_{1} \frac{n_{2}+-\sum R_{2}}{2}
\end{aligned}
$$

\section{Dimana :}

$$
\begin{array}{ll}
\mathrm{U}_{1} & =\text { statistik uji } \mathrm{U}_{1} \\
\mathrm{U}_{2} & =\text { statistik uji } \mathrm{U}_{2} \\
\mathrm{R}_{1} & =\text { jumlah rank sampel } 1 \\
\mathrm{R}_{2} & =\text { jumlah rank sampel } 2 \\
\mathrm{n}_{1} & =\text { banyaknya anggota sampel } 1 \\
\mathrm{n}_{2} & =\text { banyaknya anggota sampel } 2
\end{array}
$$

7. Diantara nilai U1 dan U2 yang lebih kecil digunakan sebagai Uhitung untuk dibandingkan dengan Utabel.

8. Jika nilai Uhitung pada nomor 7 lebih besar dari $n 1 \mathrm{n} 2 / 2$ maka nilai tersebut adalah nilai U', dan nilai $U$ dapat dihitung dengan rumus : $U=n 1 \mathrm{n} 2-\mathrm{U}^{\prime}$.

9. Kriteria pengambilan keputusan :
a. $\mathrm{H} 0$ diterima bila Uhitung $\geq$ Utabel( $a ; n 1, n 2)$.
b. $\mathrm{HO}$ ditolak bila Uhitung $\leq$ Utabel(a; $\mathrm{n} 1, \mathrm{n} 2)$.
Atau jika :
a. Nilai Asymp.Sig.(2-tailed) $>0,05$ maka $\mathrm{H}_{0}$ diterima.
b. Nilai Asymp.Sig.(2-tailed) $<0,05$, maka $\mathrm{H}_{0}$ ditolak. 


\section{HASIL ANALISIS DAN PEMBAHASAN}

Hasil pengujian terhadap 8 (delapan) indikator rasio keuangan pada Provinsi kepulauan Bangka Belitung dan Provinsi Sumatera Selatan adalah sebagai berikut :

Tabel Uji Peringkat Mann-Whitney U Test Ranks

\begin{tabular}{|c|c|c|c|c|}
\hline Rasio & Provinsi & $\mathbf{N}$ & Mean Rank & Sum of Rank \\
\hline Rasio1 & $\begin{array}{l}\text { Sumatera } \\
\text { Selatan } \\
\text { Bangka Belitung } \\
\text { Total }\end{array}$ & $\begin{array}{c}5 \\
5 \\
10\end{array}$ & $\begin{array}{l}6,90 \\
4,10\end{array}$ & $\begin{array}{l}34,50 \\
20,50\end{array}$ \\
\hline Rasio2 & $\begin{array}{l}\text { Sumatera } \\
\text { Selatan } \\
\text { Bangka Belitung } \\
\text { Total }\end{array}$ & $\begin{array}{c}5 \\
5 \\
10\end{array}$ & $\begin{array}{l}8,00 \\
3,00\end{array}$ & $\begin{array}{l}40,00 \\
15,00\end{array}$ \\
\hline Rasio 3 & $\begin{array}{l}\text { Sumatera } \\
\text { Selatan } \\
\text { Bangka Belitung } \\
\text { Total }\end{array}$ & $\begin{array}{c}5 \\
5 \\
10\end{array}$ & $\begin{array}{l}3,00 \\
8,00\end{array}$ & $\begin{array}{l}15,00 \\
40,00\end{array}$ \\
\hline Rasio 4 & $\begin{array}{l}\text { Sumatera } \\
\text { Selatan } \\
\text { Bangka Belitung } \\
\text { Total }\end{array}$ & $\begin{array}{c}5 \\
5 \\
10\end{array}$ & $\begin{array}{l}7,50 \\
3,50\end{array}$ & $\begin{array}{l}37,50 \\
17,50\end{array}$ \\
\hline Rasio 5 & $\begin{array}{l}\text { Sumatera } \\
\text { Selatan } \\
\text { Bangka Belitung } \\
\text { Total }\end{array}$ & $\begin{array}{c}5 \\
5 \\
10\end{array}$ & $\begin{array}{l}7,20 \\
3,80\end{array}$ & $\begin{array}{l}36,00 \\
19,00\end{array}$ \\
\hline Rasio 6 & $\begin{array}{l}\text { Sumatera } \\
\text { Selatan } \\
\text { Bangka Belitung } \\
\text { Total }\end{array}$ & $\begin{array}{c}5 \\
5 \\
10\end{array}$ & $\begin{array}{l}6,70 \\
4,30\end{array}$ & $\begin{array}{l}33,50 \\
21,50\end{array}$ \\
\hline Rasio 7 & $\begin{array}{l}\text { Sumatera } \\
\text { Selatan } \\
\text { Bangka Belitung } \\
\text { Total }\end{array}$ & $\begin{array}{c}5 \\
5 \\
10\end{array}$ & $\begin{array}{l}8,00 \\
3,00\end{array}$ & $\begin{array}{l}40,00 \\
15,00\end{array}$ \\
\hline Rasio 8 & $\begin{array}{l}\text { Sumatera } \\
\text { Selatan } \\
\text { Bangka Belitung } \\
\text { Total }\end{array}$ & $\begin{array}{c}5 \\
5 \\
10\end{array}$ & $\begin{array}{l}8,00 \\
3,00\end{array}$ & $\begin{array}{l}21,00 \\
34,00\end{array}$ \\
\hline
\end{tabular}

Sumber : Data olahan (2020)

Tabel Hasil Uji Mann-Whitney

\begin{tabular}{|l|r|r|r|r|r|r|r|c|}
\hline & Rasio & Rasio & Rasio & Rasio & Rasio & Rasio & Rasio & Rasio \\
& $\mathbf{1}$ & $\mathbf{2}$ & $\mathbf{3}$ & $\mathbf{4}$ & $\mathbf{5}$ & $\mathbf{6}$ & $\mathbf{7}$ & $\mathbf{8}$ \\
\hline Mann-Whitney U & 5,500 &, 000 &, 000 & 2,500 & 4,000 & 6,500 &, 000 & 6,000 \\
Wilcoxon W & 20,500 & 15,000 & 15,000 & 17,500 & 19,000 & 21,500 & 15,000 & 21,000 \\
Z & -1.519 & $-2,611$ & $-2,619$ & $-2,095$ & $-1,781$ & -1.273 & $-2,611$ & $-1,358$ \\
Asymp.Sig. (2-tailed) &, 129 &, 009 &, 009 &, 036 &, 075 &, 203 &, 009 &, 175 \\
Exact Sig.[2*(1-tailed &, $151^{\mathrm{b}}$ &, $008^{\mathrm{b}}$ &, $008^{\mathrm{b}}$ &, $032^{\mathrm{b}}$ &, $095^{\mathrm{b}}$ &, $222^{\mathrm{b}}$ &, $008^{\mathrm{b}}$ &, $222^{\mathrm{b}}$ \\
\hline Sig.)] & & & & & & & & \\
\hline
\end{tabular}

Sumber : Output Mann-Whitney 
Sementara hasil perbandingan rata-rata rasio keuangan daerah selama tahun 20142018 antara Provinsi Kepulauan Bangka Belitung dan Provinsi Sumatera Selatan dapat dilihat pada tabel dibawah ini :

Tabel Perbandingan Rata-rata Rasio Keuangan Daerah Provinsi Kepulauan Bangka Belitung dan Provinsi Sumatera Selatan Tahun 2014-2018

\begin{tabular}{|c|c|c|c|c|c|}
\hline \multirow[t]{2}{*}{ Rasio } & \multirow[t]{2}{*}{ Nama Rasio } & \multicolumn{2}{|c|}{ Rata-rata Rasio } & \multirow[t]{2}{*}{ Ket } & \multirow[t]{2}{*}{ Hasil Uji } \\
\hline & & Babel & Sumsel & & \\
\hline 1 & Rasio Pajak & 0,009 & 0,007 & $\begin{array}{c}\text { Tidak } \\
\text { Lebih } \\
\text { Baik }\end{array}$ & $\begin{array}{c}\text { Ada } \\
\text { Perbedaan }\end{array}$ \\
\hline 2 & $\begin{array}{l}\text { Rasio Ruang } \\
\text { Fiskal }\end{array}$ & 2,02 & 0,72 & $\begin{array}{c}\text { Lebih } \\
\text { Baik }\end{array}$ & $\begin{array}{c}\text { Tidak Ada } \\
\text { Perbedaan }\end{array}$ \\
\hline 3 & $\begin{array}{c}\text { Rasio } \\
\text { Kemandirian } \\
\text { Daerah }\end{array}$ & 0,48 & 0,68 & $\begin{array}{l}\text { Lebih } \\
\text { Baik }\end{array}$ & $\begin{array}{l}\text { Tidak Ada } \\
\text { Perbedaan }\end{array}$ \\
\hline 4 & $\begin{array}{l}\text { Rasio Belanja } \\
\text { Pegawai } \\
\text { Terhadap Total } \\
\text { Belanja Daerah }\end{array}$ & 0,24 & 0,16 & $\begin{array}{l}\text { Lebih } \\
\text { Baik }\end{array}$ & $\begin{array}{c}\text { Tidak Ada } \\
\text { Perbedaan }\end{array}$ \\
\hline 5 & $\begin{array}{l}\text { Rasio Belanja } \\
\text { Pegawai Tidak } \\
\text { Langsung } \\
\text { Terhadap Total } \\
\text { Belanja Daerah }\end{array}$ & 0,22 & 0,15 & $\begin{array}{c}\text { Tidak } \\
\text { Lebih } \\
\text { Baik }\end{array}$ & $\begin{array}{c}\text { Ada } \\
\text { Perbedaan }\end{array}$ \\
\hline 6 & $\begin{array}{l}\text { Rasio Belanja } \\
\text { Modal Terhadap } \\
\text { Total Belanja } \\
\text { Daerah }\end{array}$ & 0,41 & 0,39 & $\begin{array}{c}\text { Tidak } \\
\text { Lebih } \\
\text { Baik }\end{array}$ & $\begin{array}{c}\text { Ada } \\
\text { Perbedaan }\end{array}$ \\
\hline 7 & $\begin{array}{c}\text { Rasio Belanja } \\
\text { Daerah } \\
\text { Terhadap Jumlah } \\
\text { Penduduk }\end{array}$ & 3.236 .938 & 770.629 & $\begin{array}{l}\text { Lebih } \\
\text { Baik }\end{array}$ & $\begin{array}{l}\text { Tidak Ada } \\
\text { Perbedaan }\end{array}$ \\
\hline 8 & $\begin{array}{c}\text { Rasio Belanja } \\
\text { Modal Terhadap } \\
\text { Jumlah } \\
\text { Penduduk }\end{array}$ & 636.206 & 189.267 & $\begin{array}{c}\text { Tidak } \\
\text { Lebih } \\
\text { Baik }\end{array}$ & $\begin{array}{c}\text { Ada } \\
\text { Perbedaan }\end{array}$ \\
\hline
\end{tabular}

Sumber : Data olahan (2020)

Berdasarkan tabel diatas, maka kondisi keuangan Provinsi Kepulauan Bangka Belitung dan Provinsi Sumatera Selatan tahun 2014-2018 dapat dijelaskan sebagai berikut:

1. Rasio pajak.

Ada perbedaan tingkat kemampuan daerah dalam menghasilkan penerimaan pajak daerah selama tahun anggaran 2014-2018 antara Provinsi Kepulauan Bangka Belitung dan Pemerintah Sumatera Selatan. Secara rata-rata hasil perhitungan rasio pajak Provinsi Kepulauan Bangka Belitung sebesar 0,009 persen dan Provinsi Sumatera Selatan sebesar 0,007 persen. 
2. Rasio Ruang Fiskal.

Tidak Ada perbedaan terkait fleksibilitas yang dimiliki oleh pemerintah daerah dalam mengalokasikan APBD untuk membiayai kegiatan yang menjadi prioritas daerah selama tahun anggaran 2014-2018 antara Provinsi Kepulauan Bangka Belitung dan Pemerintah Sumatera Selatan.Secara rata-rata hasil perhitungan rasio ruang fiskal Provinsi Kepulauan Bangka Belitung sebesar 2,02 persen dan Provinsi Sumatera Selatan sebesar 0,72 persen.

3. Rasio Kemandirian Daerah.

Tidak ada perbedaan terkait kemampuan daerah dalam membiayai kebutuhannya melalui PAD selama tahun anggaran 2014-2018. Secara rata-rata rasio kemandirian daerah Provinsi Kepulauan Bangka Belitung sebesar 0,48 persen dan Provinsi Sumatera Selatan sebesar 0,68 persen.

4. Rasio Belanja Pegawai Terhadap Total Belanja Daerah.

Tidak ada perbedaan dalam pengalokasian belanja pegawai daerah selama tahun anggaran 2014-2018 antara Provinsi Kepulauan Bangka Belitung dan Pemerintah Sumatera Selatan. Secara rata-rata hasil perhitungan Rasio Belanja Pegawai Terhadap Total Belanja Daerah Provinsi Kepulauan Bangka Belitung sebesar 0,24 persen dan Provinsi Sumatera Selatan sebesar 0,16 persen.

5. Rasio Belanja Pegawai Tidak Langsung Terhadap Total Belanja Daerah.

Ada perbedaan terkait rasio belanja pegawai tidak langsung terhadap total belanja daerah yang mencerminkan porsi belanja daerah terhadap pembayaran gaji pegawai PNSDselama tahun anggaran 2014-2018 antara Provinsi Kepulauan Bangka Belitung dan Pemerintah Sumatera Selatan. Secara rata-rata hasil rasio belanja pegawai tidak langsung terhadap total belanja daerah untuk Provinsi Kepulauan Bangka Belitung sebesar 0,22 persen dan Pemerintah Provinsi Sumatera Selatan Sebesar 0,15 persen.

6. Rasio Belanja Modal Terhadap Total Belanja Daerah.

Ada perbedaanrasio belanja modal terhadap total belanja daerah. Belanja mencerminkan porsi belanja daerah yang dibelanjakan Modal sendiri ditambah belanja barang dan jasa, merupakan belanja pemerintah yang memiliki pengaruh signifikan terhadap pertumbuhan ekonomi suatu daerah selain dari sektor swasta, rumah tangga, dan luar negeri. Rata-rata rasio belanja modal terhadap total belanja daerah Provinsi Kepulauan Bangka Belitung sebesar 0,41 persen dan Provinsi Sumatera Selatan sebesar 0,39 persen.

7. Rasio Belanja Daerah Terhadap Jumlah Penduduk.

Tidak ada perbedaan rasio belanja daerah terhadap jumlah penduduk. Rasio ini menunjukkan seberapa besar belanja yang digunakan untuk menyejahterakan per penduduk di suatu daerah. Rata-rata rasio belanja daerah terhadap jumlah penduduk Provinsi Kepulauan Bangka Beltung sebesar Rp. 3.236.938 dan Provinsi Sumatera Selatan sebesar Rp. 770.629.

8. Rasio Belanja Modal Terhadap Jumlah Penduduk.

Ada perbedaan rasio belanja modal terhadap jumlah penduduk. Rasio belanja modal perkapita menunjukkan seberapa besar belanja yang dialokasikan pemerintah untuk pembangunan infrastruktur daerah per penduduk. Rata-rata rasio belanja modal terhadap jumlah penduduk Provinsi Kepulauan Bangka Belitung sebesar Rp. 636.206 dan Provinsi Sumatera Selatan sebesar Rp. 189.267.

\section{E. KESIMPULAN DAN SARAN}

Berdasarkan hasil analisis diatas dapat disimpulkan bahwa Provinsi Kepulauan Bangka Belitung memiliki tingkat kondisi keuangan yang lebih baik dari pada Provinsi Sumatera Selatan atas rasio pajak,rasio belanja modal terhadap total belanja daerah dan 
rasio belanja modal terhadap jumlah penduduk sedangkan Provinsi Sumatera Selatan memiliki tingkat kondisi keuangan yang lebih baik dari Provinsi Kepulauan Bangka Belitung untuk rasio belanja pegawai tidak langsung terhadap total belanja daerah.

Berdasarkan kesimpulan yang telah disampaikan diatas maka saran yang dapat diberikan untuk mencapai kondisi keuangan yang lebih baik bagi Provinsi Kepulauan Bangka Belitung adalah mengurangi belanja pegawai tidak langsung, pengurangan tersebut sangat diperlukan untuk memperbesar belanja modal karena belanja modal yang besar memiliki pengaruh signifikan terhadap pertumbuhan ekonomi suatu daerah selain dari sektor swasta, rumah tangga, dan luar negeri.

\section{DAFTAR PUSTAKA}

Arikunto, S. (2006). Metode Penelitian Kualitatif. Jakarta: Bumi Aksara.

Badan Pusat Statistik Provinsi Kepulauan Bangka Belitung. Jumlah Penduduk Laki-Laki Menurut Kabupaten/Kota Provinsi Kep. Bangka Belitung 2001-2020.

Badan Pusat Statistik Provinsi Kepulauan Bangka Belitung. Jumlah Penduduk Perempuan Menurut Kabupaten/KotaProvinsi Kep. Bangka Belitung 2001-2020.

Badan Pusat Statistik Provinsi Sumatera Selatan. Jumlah Penduduk menurut Kabupaten/Kota di Provinsi Sumatera Selatan, 2010-2019.

Bank Indonesia. (2014). Kajian Ekonomi Keuangan Regional Provinsi Kepulauan Bangka Belitung.

Bank Indonesia. (2015). Kajian Ekonomi Keuangan Regional Provinsi Kepulauan Bangka Belitung.

Bank Indonesia. (2016). Kajian Ekonomi Keuangan Regional Provinsi Kepulauan Bangka Belitung.

Bank Indonesia. (2017). Kajian Ekonomi Keuangan Regional Provinsi Kepulauan Bangka Belitung

Bank Indonesia. (2018). Kajian Ekonomi Keuangan Regional Provinsi Kepulauan Bangka Belitung.

Bank Indonesia. 2014. Kajian Ekonomi Keuangan Regional Provinsi Sumatera Selatan.

Bank Indonesia. 2015. Kajian Ekonomi Keuangan Regional Provinsi Sumatera Selatan.

Bank Indonesia. 2016. Kajian Ekonomi Keuangan Regional Provinsi Sumatera Selatan.

Bank Indonesia. 2017. Kajian Ekonomi Keuangan Regional Provinsi Sumatera Selatan.

Bank Indonesia. 2018. Kajian Ekonomi Keuangan Regional Provinsi Sumatera Selatan. 
Kementerian Keuangan, Direktorat Jenderal Perimbangan Keuangan. Setelah Tahun 2016 APBD Gabungan Tahun 2014-2018.

Stephen S. Heller (2005). IMF Policy Discussion Paper, 2005.

Suharyadi dan Purwanto. (2008). Statistika Untuk Ekonomi dan Keuangan Modern. Edisi 2 Buku 1. Jakarta: Salemba Empat.

Suryani, Hasan Basri dan Faisal, (2016). Analisis Kondisi Keuangan Daerah Kabupaten/Kota di Aceh dan di Sumatera Utara. Jurnal Bisnis dan Ekonomi (JBE), Maret 2016, Hal.. 63-71.

Robert J. Rasdalim, Antonius Y. Luntungan, Patrick C. Wauran (2017). Analysis the Effect of RegionalFinancial Management On The Economic Growthof North Sulawesi Province. Jurnal Berkala IImiah Efisiensi. Volume 17 No.01 Tahun 2017. 